\title{
Productivity of oil flax varieties in the conditions of northern forest steppe of Tyumen region
}

\author{
Anatoly Pershakov ${ }^{1, *}$, Raisa Belkina ${ }^{1}$, Aigera Suleimenova ${ }^{2}$, and Ivan Loskomoynikov ${ }^{2}$ \\ ${ }^{1}$ Northern Trans-Ural State Agricultural University, Republiki Str., 7, 625003, Tyumen Region, \\ Tyumen, Russia \\ ${ }^{2}$ Sos - Branch Of The Fgbnu Fsc Vniimk Them. V.S. Pustovoyta, St. Builders, 2, 646025, Isilkul, \\ Omsk Region, Russia
}

\begin{abstract}
Objective of the research: to study the influence of the norms of mineral fertilizers on the yield and quality of seeds of oil flax varieties in the conditions of the northern forest-steppe of the Tyumen region. The studies were carried out on the experimental field of the State Agrarian University of the Northern Trans-Urals in 2019-2020. The soil of the experimental field is leached chernozem, thin, heavy loamy. Experimental options included: control, without fertilizers; NPK based on seed yield 2 $\mathrm{t} / \mathrm{ha}$; NPK based on seed yield of $3 \mathrm{t} / \mathrm{ha}$. Increases in yield from the use of fertilizers in the studied varieties August and Sokol were obtained in 2019, the growing season of which was characterized by the amount of precipitation close to the long-term level. In 2020, when there was a shortage of precipitation, only the Sokol variety showed a positive reaction to fertilizers. Under the influence of fertilizers, the seed oil content of the August variety decreased, while the Sokol variety was at the same level in all variants.
\end{abstract}

\section{Introduction}

Oil flax is becoming more widespread in the world, which is facilitated by the increased demand for flax seeds, which are widely used in various industries [1].

New technologies for producing flour with the addition of flax seeds are being developed. As a result, wheat flour is enriched with a number of valuable components, including polyunsaturated fatty acids, which provides the prospect of obtaining new products with high nutritional, biological and medicinal properties [2-5]. A new technology for producing wheat-flax flour has been developed. Regularities of preparation and optimal modes of grinding of binary grain mixtures have been established. Composite types of flour with increased nutritional value have been obtained. The content of linoleic acid (omega-6) in a sample of wheat-flaxseed flour is 1.6-3.3 times, and linolenic acid (omega-3) is 36.857.2 times higher than in samples of wheat flour (with taking into account the total fat content of the samples). The volumetric yield of bread baked from wheat and flax flour was

\footnotetext{
*Corresponding author: pershakov.93@mail.ru
} 
$422-449 \mathrm{~cm}^{3} / 100 \mathrm{~g}$ of flour. The bread samples were characterized by above the average total organoleptic score. The authors consider it possible to use wheat and flax flour for obtaining specialized types of bread and the production of flour confectionery products [5].

Selection plays an important role in increasing yields and improving other economically valuable traits of oil flax.

In the process of creating new varieties of flax, sources of resistance to diseases, low acidity of soils, varieties with a high oil content of seeds have been identified [6-8]. Lines of oil flax have been created with resistance to flax fatigue and high resistance to fusarium [9]. Possibilities of optimization of fatty acid composition of flaxseed oil are investigated [10-12].

In the conditions of Siberia, the variety August is distinguished by a complex of economically valuable traits. It is an early-maturing, productive variety with a high oil content in its seeds. In the region, for the development of new directions for the use of flax products, new varieties with a modified fatty acid composition of the oil are being created. Among the selection samples there are highly productive ones, with an oil content of seeds from 48.1 to $49.2 \%$, with a modified fatty acid composition of the oil [6].

In the northern forest-steppe of the Tyumen region, varieties of the world collection of oil flax have been studied. A number of samples were distinguished by high productivity (240-270 g/m²): Voronezh 1308/138 (k-5579) from Russia, Micael (k-8218) from France, Omega (k-8606) and Prairie Blue (k-8609) from Canada, Chibik (k-8710) from Ukraine. Samples with a complex of useful traits are recommended for use in breeding as a source material: domestic samples Voronezh 1308/138 (yield and oil content of seeds), Streamlet (yield, oil content and protein content in seeds), Michael and Oliver from France (yield and protein content in seeds), Omega and Prairie Blue from Canada (yield and oil content of seeds), Ba Ya No. 12 from China (yield, oil content and protein content in seeds) [14].

In the same region, the influence of seeding rates on the productivity of the oil-bearing flax variety Legur was studied. The options included 7, 8, 9, 10 million germinating seeds per hectare. The best combination of yield and elements of its structure was provided by the seeding rate of $9 \mathrm{million} / \mathrm{ha}$ : the yield was $1.78-1.81 \mathrm{t} / \mathrm{ha}$, the number of plants before harvesting $-480-520 \mathrm{pcs} / \mathrm{m}^{2}$, the number of bolls per plant $-9.8-10.2$ pcs., The mass of seeds per plant is $0.83-0.93 \mathrm{~g}$ [13].

In the conditions of the Tyumen region, as a result of studying the collection of oil flax, varieties with high productivity and quality of seeds were identified [13]. Under these conditions, the domestic varieties Sokol and Lehur formed the seed yield at the level of $1.8-2.0 \mathrm{t} / \mathrm{ha}[14]$.

The use of fertilizers should be attributed to the important elements of the technology for the cultivation of oil flax. The effectiveness of this technique is associated with varietal characteristics and soil and climatic conditions. In the zone of unstable moisture (Krasnodar Region) and in the zone of insufficient moisture (Rostov Region), the effect of fertilizers was studied in the cultivation of oil flax varieties VNIIMK 620 and Nebesny. The application of fertilizers N60 and N60P30K30 for pre-sowing cultivation, as well as N30 for fertilizing crops in the "herringbone" phase contributed to an increase in the yield of flax varieties by $0.03-0.23 \mathrm{t} / \mathrm{ha}$. As a result of the studies, it was revealed that the yield of oil flax VNIIMK 620 depends on the moisture supply during the critical period of the growing season of the crop (budding - flowering). In years with weather conditions typical for the arid zone of moisture, the yield of the crop is influenced by the moisture supply in May and June, which corresponds to the phases of "fir-tree", budding, flowering. In years with weather conditions typical for humid and slightly arid zones of moisture, the crop yield depends on the moisture supply in June, which corresponds to the phases of budding and flowering. The use of fertilizers contributed to an increase in biometric indicators and elements of the structure of the crop [15]. 


\section{Material and methods}

The studies were carried out in the zone of the northern forest-steppe of the Tyumen region on the experimental field of the State Agrarian University of the Northern Trans-Urals in 2019-2020. The soil of the experimental field is leached chernozem, thin, heavy loamy. The humus content in the arable layer $(0-30 \mathrm{~cm})$ varies from 7.65 to $9.05 \%$, deeper it decreases from 4.41 to $0.72-0.54 \%$. The gross content of nitrogen and phosphorus in the arable layer is $0.43-0.44 \%$ and $0.16-0.18 \%$, respectively [16].

Based on the characteristics of the agrochemical parameters of the soil of the experimental field and the data of the analysis of soil samples for the content of nutrients, the calculation of fertilizer rates was carried out using the balance method for the yield of oil flax seeds of 2 and $3 \mathrm{t} / \mathrm{ha}$. The studies were carried out with the varieties August and Sokol, created at the Siberian Experimental Station - a branch of the All-Russian Research Institute of Oilseeds named after V.S. Pustovoyta. The varieties are approved for cultivation in the West Siberian region.

The predecessor in the experiment is annual herbs. Plot area $10 \mathrm{~m}^{2}$, replication four times. We sowed oil flax with an SSFK-10 seeder, and harvested crops with a TERRION 2010 combine.

The oil content in the seeds was determined using an AMB-1006M NMR analyzer.

\section{Results and discussion}

In terms of the meteorological conditions of the growing season, the years of research varied significantly. The most favorable humidification conditions were typical for 2019: the amount of precipitation in May-August was $293 \mathrm{~mm}$, which is $50 \mathrm{~mm}$ higher than the average annual level. The average daily air temperature slightly exceeded the long-term level (by $0.90 \mathrm{C}$ ). The year 2020 was characterized by insufficient precipitation $(63 \mathrm{~mm}$ lower compared to the long-term level $)$ and high air temperatures $(2.40 \mathrm{C}$ higher than normal).

The yield of seeds of the flax variety August in 2019 was in the range of 1.50-2.06 t/ha (Table 1). The use of fertilizers based on a yield of $2 \mathrm{t} / \mathrm{ha}$ provided an increase of $0.29 \mathrm{t} / \mathrm{ha}$, which amounted to $19.3 \%$. With a higher fertilizer rate (NPK per $3 \mathrm{t} / \mathrm{ha}$ ), the increase reached $0.56 \mathrm{t} / \mathrm{ha}(37.3 \%)$. Under the conditions of 2020 , with a lack of moisture during the growing season, the increase in yield in options with fertilizers was minimal - at the level of $3.3 \%$.

The seed yield of flax varieties Sokol in 2019 varied from 1.48 to $1.87 \mathrm{t} /$ ha (Table 1 ). The use of fertilizers based on a yield of $2 \mathrm{t} / \mathrm{ha}$ provided a slight excess over the control $0.12 \mathrm{t} / \mathrm{ha}(8.1 \%)$. With a higher fertilizer rate (NPK by $3 \mathrm{t} / \mathrm{ha}$ ), the increase was $0.39 \mathrm{t} / \mathrm{ha}$ $(26.4 \%)$. Under the conditions of 2020, a positive reaction of the Sokol variety to fertilizers was also observed. The additions to the control according to the variants of the experiment were respectively: $0.51 \mathrm{t} / \mathrm{ha}(26.6 \%)$ and $0.50 \mathrm{t} / \mathrm{ha}(26.0 \%)$. 
Table 1. Seed yield of oil flax varieties under the influence of fertilizers, $t / h a$.

\begin{tabular}{|l|l|c|c|}
\hline $\begin{array}{c}\text { Variety. } \\
\text { factor A }\end{array}$ & \multicolumn{1}{c|}{$\begin{array}{c}\text { Option. } \\
\text { factor B }\end{array}$} & $\mathbf{2 0 1 9}$ & $\mathbf{2 0 2 0}$ \\
\hline \multirow{3}{*}{ August } & 1. Control. no fertilizer & 1.50 & 2.13 \\
\cline { 2 - 4 } & 2.NPK based on yield 2 t/ha & 1.79 & 2.18 \\
\cline { 2 - 4 } & 3.NPK based on yield 3 t/ha & 2.06 & 2.18 \\
\hline \multirow{3}{*}{ Solol } & 1. Control. no fertilizer & 1.48 & 1.92 \\
\cline { 2 - 4 } & 2.NPK based on yield 2 t/ha & 1.60 & 2.43 \\
\cline { 2 - 4 } & 3.NPK based on yield 3 t/ha & 1.87 & 2.42 \\
\hline NDS 05 for factor A & 0.26 & 0.30 \\
\hline NDS 05 for factor B & 0.27 & 0.31 \\
\hline
\end{tabular}

The number of productive plants before harvesting in the August variety in 2019 was at the level 513-547 units $/ \mathrm{m}^{2}$ (table 2). In variants with fertilizers, the number of productive plants increased relative to the control by 34 and $23 \mathrm{pcs} / \mathrm{m}^{2}$. Under the conditions of 2020 , no definite regularity was observed in the variability of this indicator under the influence of fertilizers.

Table 2. The number of plants to be harvested in oil flax varieties under the influence of fertilizers, $\mathrm{pcs} / \mathrm{m}^{2}$.

\begin{tabular}{|c|l|c|c|}
\hline $\begin{array}{c}\text { Variety, } \\
\text { factor A }\end{array}$ & \multicolumn{1}{c|}{$\begin{array}{c}\text { Option, } \\
\text { factor B }\end{array}$} & $\mathbf{2 0 1 9}$ & $\mathbf{2 0 2 0}$ \\
\hline \multirow{3}{*}{ August } & 1. Control, no fertilizer & 513 & 517 \\
\cline { 2 - 4 } & 2.NPK based on yield 2 t/ha & 547 & 505 \\
\cline { 2 - 4 } & 3.NPK based on yield 3 t/ha & 536 & 527 \\
\hline \multirow{3}{*}{ Solol } & 1. Control, no fertilizer & 429 & 496 \\
\cline { 2 - 4 } & 2.NPK based on yield 2 t/ha & 456 & 511 \\
\cline { 2 - 4 } & 3.NPK based on yield 3 t/ha & 450 & 512 \\
\hline NDS 05 for factor A & 30 & 28 \\
\hline NDS 05 for factor B & 35 & 25 \\
\hline
\end{tabular}

In the Sokol variety, the number of productive plants to be harvested in 2019 varied from 429 to $456 \mathrm{pcs} / \mathrm{m}^{2}$ (table 2). In variants with fertilizers, the number of productive plants increased relative to the control by 27 and $21 \mathrm{pcs} / \mathrm{m}^{2}$. The positive effect of fertilizers on the value of this indicator was also observed under the conditions of 2020. The increase in comparison with the control according to the variants of the experiment was 15 and $16 \mathrm{pcs} / \mathrm{m}^{2}$.

It should be noted that this indicator for the August cultivar was higher than that of the Sokol cultivar: in 2019, on average, for the experimental variants by $87 \mathrm{pcs} / \mathrm{m}^{2}$, in $2020-$ by $10 \mathrm{pcs} / \mathrm{m}^{2}$.

Another element of the yield structure - the mass of seeds per plant was subject to insignificant variability under the influence of fertilizers. In the cultivar August in both years of research, there was a tendency to an increase in the indicator in the variants with fertilizers relative to the control. In 2019, the values were according to the variants of the experiment: $0.579 \mathrm{~g} ; 0.616 \mathrm{~g} ; 0.627 \mathrm{~g}$; in 2020 corresponded to: $0.609 \mathrm{~g} ; 0.667 \mathrm{~g} ; 0.646 \mathrm{~g}$. It should be noted that the weight of seeds per plant in this variety under the conditions of 2020 was formed on average by $0.34 \mathrm{~g}$ higher than in the conditions of the previous year. In the Sokol variety, the mass of seeds per plant in the variants of the experiment in 2019 corresponded to the following values: $0.589 \mathrm{~g} ; 0.593 \mathrm{~g}$; $0.593 \mathrm{In} 2020$, the indicators were slightly higher: $0.602 \mathrm{~g} ; 0.611 \mathrm{~g} ; 0.615 \mathrm{~g}$. The difference in mean values was $0.17 \mathrm{~g}$.

The oil content of flax seeds of the August variety decreased under the influence of fertilizers (Table 3). In 2019, the indicators in variants with fertilizers were lower by 3.6$4.8 \%$, in 2020 - by $2.2-3.4 \%$. In the Sokol variety, the oil content of seeds in the control 
and in variants with fertilizers was practically at the same level: in 2019 - from 44.0 to $44.5 \%$, in 2020 - from 42.9 to $43.3 \%$.

Table 3. The mass of seeds per plant in oil flax varieties under the influence of fertilizers, $g$.

\begin{tabular}{|c|c|c|c|}
\hline $\begin{array}{l}\text { Variety. } \\
\text { factor a }\end{array}$ & $\begin{array}{l}\text { Option. } \\
\text { factor B }\end{array}$ & 2019 & 2020 \\
\hline \multirow{3}{*}{ August } & 1. Control. no fertilizer & 0.579 & 0.609 \\
\hline & 2.NPK based on yield $2 \mathrm{t} / \mathrm{ha}$ & 0.616 & 0.667 \\
\hline & 3.NPK based on yield $3 \mathrm{t} / \mathrm{ha}$ & 0.627 & 0.646 \\
\hline \multirow{3}{*}{ Sokol } & 1. Control. no fertilizer & 0.589 & 0.602 \\
\hline & 2.NPK based on yield $2 \mathrm{t} / \mathrm{ha}$ & 0.593 & 0.611 \\
\hline & 3.NPK based on yield $3 \mathrm{t} / \mathrm{ha}$ & 0.593 & 0.615 \\
\hline \multicolumn{2}{|c|}{ NPK 05 for factor $\mathrm{A}$} & \multicolumn{2}{|c|}{0.021} \\
\hline \multicolumn{2}{|c|}{ NPK 05 for factor B } & \multicolumn{2}{|c|}{0.020} \\
\hline
\end{tabular}

In the August variety, the mass of seeds per plant was slightly higher in comparison with the Sokol variety. In 2019, the differences on average for the variants of the experiment were $0.015 \mathrm{~g}$, in $2020-0.032 \mathrm{~g}$.

The oil content of flax seeds of the August variety decreased under the influence of fertilizers (Table 4). In 2019, the indicators in variants with fertilizers were lower by 3.6$4.8 \%$, in 2020 - by $2.2-3.4 \%$. In the Sokol variety, the oil content of seeds in the control and in variants with fertilizers was practically at the same level: in 2019 - from 44.0 to $44.5 \%$, in 2020 - from 42.9 to $43.3 \%$.

Table 4. Oil content of flax seeds under the influence of fertilizers, $\%$.

\begin{tabular}{|c|l|l|l|}
\hline Variety & \multicolumn{1}{|c|}{ Option } & \multicolumn{1}{|c|}{$\mathbf{2 0 1 9}$} & \multicolumn{1}{|c|}{$\mathbf{2 0 2 0}$} \\
\hline \multirow{3}{*}{ August } & 1. Control. no fertilizer & 48.8 & 45.9 \\
\cline { 2 - 4 } & 2.NPK based on yield 2 t/ha & 44.0 & 43.7 \\
\cline { 2 - 4 } & 3.NPK based on yield 3 t/ha & 45.2 & 42.5 \\
\hline \multirow{3}{*}{ Sokol } & 1. Control. no fertilizer & 44.0 & 43.3 \\
\cline { 2 - 4 } & 2.NPK based on yield 2 $/ \mathrm{ha}$ & 44.4 & 42.9 \\
\cline { 2 - 4 } & 3.NPK based on yield 3 t/ha & 44.5 & 43.3 \\
\hline
\end{tabular}

It should be noted that the seeds of the August variety had an advantage in oil content in comparison with the seeds of the Sokol variety: in 2019, the differences averaged $1.7 \%$, in $2020-0.8 \%$.

\section{The discussion of the results}

The effect of fertilizers on the yield of oil flax was determined by the varietal characteristics and moisture supply of the growing season. Increases in yield from the use of fertilizers in the varieties August and Sokol were obtained in 2019, the growing season of which was characterized by the amount of precipitation close to the long-term level. In 2020, when there was a deficit of precipitation, only the Sokol variety showed a positive reaction to fertilizers; the increase in yield in variants with fertilizers relative to the control was $26.0-26.6 \%$.

Under the influence of fertilizers, such an indicator as the number of plants before harvesting increased: for the August variety in 2019, for the Sokol variety - in both years of research. It should be noted that this indicator for the August cultivar was higher than that of the Sokol cultivar: in 2019, on average, according to the experimental variants, by 87 $\mathrm{pcs} / \mathrm{m}^{2}$, in $2020-$ by $10 \mathrm{pcs} / \mathrm{m}^{2}$. 
The mass of seeds per plant was subject to insignificant variability under the influence of fertilizers. In the varieties, there was only a tendency for the indicator to increase in the variants with fertilizers relative to the control.

The specificity of the varieties manifested itself in the oil content of seeds. Under the influence of fertilizers, the seed oil content of the August variety decreased: in 2019, from $48.8 \%$ to $44.0 \%$; in 2020 - from $45.9 \%$ to $42.5 \%$. In the Sokol variety in all variants, the seed oil content was practically at the same level in $2019,44.0-44.5 \%$; in $2020-42.9$ $43.3 \%$.

\section{Conclusions}

1. Under the conditions of the northern forest-steppe of the Tyumen region in years differing in the moisture supply of the growing season, the calculated rates of mineral fertilizers ensured the yield of flax seeds of the August variety at the level of 1.79-2.18 t/ha, of the Sokol variety $-1.60-2.42 \mathrm{t} / \mathrm{ha}$.

2. The largest increase in yield for the August variety $(0.56 \mathrm{t} / \mathrm{ha})$ was obtained in 2019 in the NPK version, calculated for a yield of $3 \mathrm{t} / \mathrm{ha}$; for the Sokol variety, the highest yield increase $(0.51 \mathrm{t} / \mathrm{ha})$ was obtained under the conditions of 2020 in the NPK variant, calculated for a yield of $2 \mathrm{t} / \mathrm{ha}$.

3. Fertilization had a positive effect on the number of productive stems in the August cultivar under the conditions of 2019, and in the Sokol cultivar in both years of research.

4. Under the influence of fertilizers, the seed oil content of the August variety decreased, while the Sokol variety was at the same level in all variants. The maximum seed oil content in the August cultivar reached $48.8 \%$, in the Sokol cultivar $-44.5 \%$.

\section{Acknowledgements}

The work was carried out within the framework of the State Assignment of the Ministry of Agriculture of the Russian Federation: Development of effective elements of the technology for the cultivation of oil flax in the conditions of the Northern Trans-Urals.

\section{References}

1. E.N. Turin, A.N. Susskiy, R.S. Stukalov, et al., IOP Conference Series: Earth and Environmental Science 640, 1-6 (2021) DOI: 10.1088/1755-1315/640/4/042014

2. E.P. Meleshkina, G.N. Pankratov, I.S. Vitol, R.Kh. Kandrokov, Russian Agricultural Sciences 2, 54 (2019) DOI: 10.30850/vrsn/2019/2/54-58/

3. G.N. Pankratov, E.P. Meleshkina, I.S. Vitol et al., Food systems 3(3), 14-19 (2020) DOI: $10.21323 / 2618-9771-2020-3-3-14-19$

4. Pankratov G. N., Meleshkina E. P., Vitol I. S., et al., Russian agricultural science 3, 6570 (2020) DOI: 10.31857/S2500262720030163

5. G.N. Pankratov, E.P. Meleshkina, I.S. Vitol et al., Food industry 2, $55-59$ (2021) DOI: 10.24412/0235-2486-2021-2-0019

6. A. Suleimenova, International agricultural journal 3(62), 146-154 (2019) DOI: 10.1007/s10722-020-00882-y7

7. T.A. Rozhmina, Jr.A.A. Zhuchenko, N.V. Melnikova, A.D. Smirnova, Agricultural Science Euro-North-East 21(2), 133-140 (2020) https://doi.org/10.30766/20729081.2020.21.2.133-140 
8. T.A. Rozhmina, A.A. Zhuchenko, I.A. Kuzemkin et al., Achievements of science and technology of agriculture 33(9), 28-31 (2019) DOI: 10.24411/0235-2451-2019-10906

9. V.M. Lukomets, S.V. Zelentsov Bulletin of the Russian Agricultural Science 2, 19-23 (2019) DOI: 10.30850/vrsn/2019/2/19-23

10. L.V. Povkhova, P. Kezimana, G.S. Krasnov et al., Systems Biology and Bioinformatics (SBB-2020): The Twelfth International Young Scientists School (ICG SB RAS, Novosibirsk, 2020) DOI 10.18699/SBB-2020-00.

11. V.I. Boev, A.I. Moskalenko, S.L. Belopukhov, N.M. Przheval'skii, Russian Journal of Organic Chemistry 51(4), 493-497 (2015)

12. A.I. Moskalenko, S.L. Belopukhov, A.A. Ivlev, V.I. Boev, Russian Journal of Organic Chemistry 47(7), 1091-1096 (2011)

13. A.Yu. Pershakov, R.I. Belkina, V.S. Ramazanova, Bulletin of the Buryat State Agricultural Academy named after V.R. Filippov 2(59), 29-35 (2020) DOI: 10.34655/bgsha.2020.59.2.004

14. A.Yu. Pershakov, R.I. Belkina, Bulletin of KrasGAU 12(165), 40-45 (2020) DOI: 10.36718/1819-4036-2020-12-40-45

15. Yu.V. Mamyrko, A.S. Bushnev, Changes in the elements of the structure of the oilseed flax crop depending on hydrothermal conditions, the use of fertilizers and the seed seeding rate 1(67), 11-16 (2020) DOI: 10.31367/2079-8725-2020-67-1-11-16

16. D.I. Eremin, Eurasian soil science 49(5), 538-545 (2016) DOI: $10.1134 /$ S1064229316050033 